\title{
Cross-Listing of Korean Companies on Foreign Exchanges : Law and Policy
}

\author{
Hwa-Jin Kim *
}

\begin{abstract}
The Korean case may be the only example that shows governmental adoption of the piggybacking paradigm focusing on cross-listing. The story of Korea is particularly interesting because it tells us the opposite of what many developing countries pursue in respect of migration of their firms to foreign markets. What caused Korea to adopt such a policy? Perhaps, it was the exogenous shocks it experienced durign the financial crisis in 1997 followed by the involvement of international lending agencies in an unprecedent sweeping reform process. This essay reviews current discussions on the relations between cross-listing and corporate governance reform from a Korean perspective. Being largely descriptive, this essay focuses on the Korean government's new policy towards corporate sector and capital markets reforms through cross-listing of the Korean firms on foreign exchanges. After a quick introduction to some empirical findings on market reaction to cross-listings of Korean companies, it discusses recent change in regulations that govern the cross-listing of Korean companies on foreign exchanges as well as that of foreign companies on Korean exchanges. This essay concludes by putting the Korean situation in context of the on-going academic discussions on competition among stock exchanges and regulatory competition on an international scale.
\end{abstract}

* Lecturer in Law, Stanford Law School; Senior Counsel, Woo Yun Kang Jeong \& Han, Seoul. Dr. Jur. (Munich); LL.M. (Harvard). The author is grateful to Korea Securities Depository, Woo Yun Kang Jeong \& Han, Korea Association for Chief Financial Officer, and KOSDAQ Listed Companies Association for their sponsorships of Stanford Law School International Conference on Cross-Listing of Emerging Market Companies on Foreign Exchanges, November 2002. The author gratefully acknowledges the invaluable assistance from Alan Kim, Seong Koo Cheong, Kevin Pak and Colin Nam. 



\section{Shift in Economic Policy and Cross-Listing}

In its efforts to spur further economic growth, the Korean government has been searching for alternatives to the traditional Chaebol-dominated economic system, ${ }^{1)}$ which alternatives relate to the policy trend towards dispersed ownership and decentralization of economic power. One of the alternatives the government has seized upon is to support start-up companies, in particular through cross-listing.

Cross-listing of Korean companies has never been easy, due to the financial and legal hurdles involved. As of March 2002, only about 35 Korean companies are crosslisted out of some 1,500 public companies. Seven companies are listed on the New York Stock Exchange or Nasdaq, ${ }^{2)}$ three companies on the London Stock Exchange, and the remainder is listed on the Luxembourg Stock Exchange. All of these companies are relatively large, with sufficient financial reserves necessary to bankroll such a costly undertaking. ${ }^{3)}$

Currently, KOSDAQ, the securities market created particularly to support Korean start-up companies, is underdeveloped. Typically, any start-up company will have extremely weak financing abilities, and have poor access to skilled management and finance professionals. Further, start-ups in Korea have the additional disadvantage of not being able to benefit from the services of venture capitalists the way U.S. start-ups do, as the venture capitalists in both countries perform different functions due in part to the fact that Korea does not have a properly developed securities market to support start-ups. Thus, Korea has a classic chicken and egg problem. ${ }^{4)}$ It is unfortunate that so

1) See generally Byung-Nak Song, The Rise of the Korean Economy (2nd ed. 1997); Bernard Black et al., Corporate Governance in Korea at the Millennium: Enhancing International Competitiveness, 26 Journal of Corporation Law 537 (2001); Myung Hun Kang, The Korean Business Conglomerate: Chaebol Then and Now (1996).

2) See Table 1.

3) During the years 1999 to 2001, for example, 105 Korean companies issued CBs in the total amount of USD117 million overseas. Also, during the same period, 114 Korean companies issued BWs in the total amount equal to USD1.26 billion and, as of late 2001, 35 Korean companies, including one KOSDAQ-registered company, had issued DRs in the amount reaching USD17.42 billion overseas. KOSDAQ-registered companies have also been active in raising capital through the issuance of CBs and BWs on foreign capital markets. For example, in 2001 alone, 131 KOSDAQ companies raised capital in foreign capital markets in the amount of roughly USD1.07 billion.

4) Cf. Bernard Black and Ronald J. Gilson, Does Venture Capital Require an Active Stock Market?, Journal of Applied Corporate Finance 36 (Winter 1999) and 2-2 Korean Journal of Securities Law 349 (2001) (Korean translation) (examining the link between an active stock market and a strong venture capital market); Haksoo Ko and 
many start-ups with excellent technology cannot maximize their potential due to the lack of financial and other managerial support.

Fortunately, the Korean government has recently expressed its commitment to boost the KOSDAQ market, and to support quality start-up companies. In this regard, it has come to focus on the cross-listing of start-ups, and now cross-listing is one of the highest priority issues on its policy agenda. The Korean government has even announced that until 2005, it will support some 20 firms in their efforts to become listed on Nasdaq. Although this policy announcement may have been made in a quite ambitious fashion largely for political reasons, it indicates the Korean government's determination to support start-ups to spur future economic growth. The Korean Ministry of Information and Communication is even sponsoring an investment fund that has been created for this particular purpose. ${ }^{5}$

The Korean government had previously allowed the Korean firms to cross-list only DRs, ${ }^{6}$ not ordinary shares, because of its concern that holders of ordinary shares listed in, for example, the U.S. would have an informational advantage over holders of ordinary shares listed in Korea due to differing disclosure requirements and levels of sophistication. Thus, foreigners could only acquire ordinary Korean shares through Korean exchanges or withdrawal of the underlying shares of the DRs, even if the company were cross-listed on a foreign exchange.

Hyun Young Shin, Venture Capital in Korea? Special Law to Promote Venture Capital Companies, 15 American University International Law Review 457 (2000). See also Edward B. Rock, Greenhorns, Yankees and Cosmopolitans: Venture Capital, IPOs, Foreign Firms and U.S. Markets, 2 Theoretical Inquiries in Law 711 (2001).

5) See Korea Economic Daily, Jan. 7, 2002, at 2 (reporting that the USD50 million fund would help qualified startups in the information technology area go to the Nasdaq).

6) American Depository Receipts (“ADRs”) are preferred to ordinary shares by the foreign issuers for various reasons: (i) Certain institutional investors in the U.S. are not allowed to invest in foreign securities denominated in foreign currency; (ii) Sale and purchase of ADRs are not taxable events in many jurisdictions; (iii) There is no inconvenience related to exchanging to and from foreign currency for the investors; (iv) ADRs are favorable to the controlling shareholders and management in terms of maintaining their control because ADR holders cannot easily exercise their voting rights in the shareholders meeting of the issuing company. Also, it is easy to monitor the trading of ADRs through the depositary institution; (v) For most foreign companies, it is almost impossible to know the whereabouts of the shareholders in the U.S. because they usually do not bother to update their contact information for the company abroad. However, in the case of ADRs, the whereabouts of the holders may easily be obtained through the depositary institution, or the company discharges its obligation to notify the holders through notification to the depositary institution. For the law and practice of ADR programs, see generally Edward F. Greene et al., U.S. Regulation of the International Securities and Derivatives Markets (6th ed., 2001). 
In January 2002, however, in addition to the announcement of its plan to support start-ups through cross-listing, the Korean government shifted its policy, thus allowing Korean firms to cross-list ordinary shares on certain designated foreign exchanges. The Korea Securities Depository (“KSD”), a legal entity established under the Korean Securities and Exchange Act is actively working to establish the necessary infrastructure for cross-listing shares of Korean companies abroad. For instance, the KSD has recently concluded service agreement with the Japan Securities Clearing Corporation and will do the same with Clearstream Banking Frankfurt (Germany) to assist Korean companies trying to list on the Tokyo Stock Exchange's Mothers and Neuer Markt (a subsidiary of the Deutsche Börse AG), respectively. It is expected that the first Korean companies will cross-list in Japan and Germany within 2002.'

\section{Cross-Listing in the Context of Corporate Sector Reform}

\section{A. Corporate Governance and Cross-Listing}

Korea has always experienced the various lengthy stages of Western capitalism's development within a much shorter period of time. Korea's experience regarding corporate governance and managerial accountability is no exception. The internationalization of Korean capital markets since the 1997 financial crisis has caused many Korean firms to begin thinking seriously about shareholder value. Since then, the Korean government has also made various efforts to reform corporate governance and managerial accountability-some of them successful, some not. ${ }^{8)}$ As a

7) While it remains questionable how many investors abroad actually will be interested in ordinary shares of young Korean companies, for many this is still major progress. The overall cost of cross-listing of ordinary shares will most likely be less than that of issuance of debt securities abroad. However, cross-listing of ordinary shares in the U.S. may take some more time because financial institutions in the U.S. are reportedly not amenable to such changes. Therefore, for the time being, the Korea's efforts are directed toward non-U.S. markets, including Japan and Germany.

8) See Table 4. See generally Hwa-Jin Kim, Toward the "Best Practice" Model in a Globalizing Market: Recent Developments in Korean Corporate Governance, 2 Journal of Corporate Law Studies 345 (2002); Hwa-Jin Kim, Taking International Soft Law Seriously: Its Implications for Global Convergence in Corporate Governance, 1 Journal of Korean Law 1 (2001); Hwa-Jin Kim, Living with the IMF: A New Approach to Corporate Governance and Regulation of Financial Institutions in Korea, 17 Berkeley Journal of International Law 61 (1999). 
recent study documented, corporate governance is an important factor explaining firm value and firm return in the Korean market.9)

However, despite the increasing awareness and efforts to improve corporate governance since 1997, most Korean public companies have until now, including even those companies cross-listed on the NYSE or Nasdaq, paid no mind to the private ordering. Rather, cross-listing on foreign exchanges has been viewed primarily as a means of enhancing global visibility, ${ }^{10)}$ even more so than raising financing. ${ }^{11)}$ This is understandable, given the high concentration of ownership ${ }^{12)}$ and the substantial private benefits of control attendant thereto, ${ }^{13)}$ coupled with the fact that qualitative requirements for listing on U.S. exchanges ${ }^{14)}$ can be waived for non-U.S. firms. ${ }^{15)}$ However, it is now time to make structural improvements to corporate governance and managerial accountability through reforms in the international securities markets. Cross-listing is an excellent mechanism to allow Korea to piggyback such reform efforts on foreign systems. ${ }^{16}$

9) This study showed that an increase in corporate governance index by 10 (out of 100) units results into an increase of Tobin's Q by 0.003 or market-to-book ratio by 0.007 . It also showed that an increase in corporate governance index by 10 units increases the level of excess return by 4-6\% over a year period. See Bernard S. Black, Hasung Jang and Woochan Kim, Does Corporate Governance Matter? Evidence from the Korean Market (AICG Conference Paper, May 2002) available at 〈http://www.aicg.org〉. Cf. Bernard Black, The Corporate Governance Behavior and Market Value of Russian Firms, 2 Emerging Markets Review 89 (2001).

10) $C f$. H. Kent Baker, John R. Nofsinger and Daniel G. Weaver, International Cross-Listing and Visibility (NYSE Working Paper 99-01, January 1999).

11) See Korea Economic Daily, April 6, 1998, at 7 (urging the Korean companies to go get financed through the cross-listing on NYSE after fulfilling the quantitative and qualitative listing requirements).

12) See Table 3.

13) See Kee-Hong Bae, Jun-Koo Kang and Jin-Mo Kim, Tunneling or Value Addition? Evidence from Mergers by Korean Business Groups (Working Paper, October 2000) available at <http://papers.ssrn.com/sol3/papers. cfm?abstract_id=246621> (SSRN) (using merger activity data in Korea during the period 1981-1997).

14) See generally Douglas C. Michael, Untenable Status of Corporate Governance Listing Standards Under the Securities Exchange Act, 47 Business Lawyer 1461 (1992).

15) See generally Roberta Karmel, The Future of Corporate Governance Listing Requirements, 54 SMU Law Review 325 (2001); James A. Fanto, The Absence of Cross-Cultural Communication: SEC Mandatory Disclosure and Foreign Corporate Governance, 17 Northwestern Journal of International Law and Business 119, 205 (1996) (arguing that "SEC mandatory disclosure does not now encourage foreign issuers to explain adequately and meaningfully their corporate governance practices to U.S. investors"). It should be noted, however, that the Sarbanes-Oxley Act of 2002 contains substantive U.S. corporate governance requirements that apply to non-U.S. companies listed on a U.S. exchange.

16) Korean companies are not allowed to incorporate or reincorporate in foreign countries. Like Germany, Korea 
In contrast to large Korean public companies, start-ups, with their substantially different ownership structure and financing needs, have much stronger motivations to cross-list, and despite having the same ability as large companies to obtain waivers of the qualitative U.S. listing requirements, they may voluntarily subject themselves to such listing requirements, so as to maximize their attractiveness to foreign investors. ${ }^{17)}$ Their ownership structure is different due to the fact that: (i) the private benefit of control are much less for these smaller companies; (ii) their managers usually have personal incentives (through stock options) to accomplish high returns on equity programs; and (iii) KOSDAQ's qualitative listing requirements are relatively strict. ${ }^{18)}$ Bonding through cross-listing may substantially increase their firm value and shareholder wealth while there is no obstructive rent-seeking controlling shareholders. ${ }^{19)}$

\section{B. Cross-Listing as Bonding Mechanism}

In January of 2000, the Korean government disclosed plans to allow Korean firms listed on the Korea Stock Exchange or KOSDAQ to list their stocks on foreign exchanges by eliminating current regulations that prohibited local/foreign cross listing.

subscribes to the real seat rule. See Art. 617 of the Korean Commercial Code and Art. 16 of the Korean International Private Law. However, the real seat rule experienced a destabilization, at least in Germany, through the Centros decision of the European Court of Justice on March 9, 1999. See Centros Ltd. v. Erhvervs-og Selskabsstyrelsen (Case C-212/97), 2 Common Market Law Reports 551 (1999). For discussions, see Ronald J. Gilson, Globalizing Corporate Governance: Convergence of Form or Function, 49 American Journal of Comparative Law 329, 350- 356 (2001) and id. at 353 ("Centros invites German venture capitalists and entrepreneurs to select a jurisdiction whose corporate law is more favorable to venture capital contracting - say, the U.K. - and then register the newly formed corporation in Germany.")

17) But see Amir N. Licht, Managerial Opportunism and Foreign Listing: Some Direct Evidence, 22 University of Pennsylvania Journal of International Economic Law 325 (2001) (arguing that foreign listings may be guided by managerial opportunism with a view to avoid the home country regulations).

18) KOSDAQ has recently adopted more strict ownership dispersion requirements for enrolled firms, and introduced more advanced disclosure and market monitoring systems. Effective as of April 1, 2000, a company that intends to register with KOSDAQ must satisfy the new ownership dispersion requirement. See the KOSDAQ Rules, art 4. The full text of the KOSDAQ Rules is available in 〈http://www.ksda.or.kr>. As abusive practices by controlling shareholders is also on the rise along with the boom in KOSDAQ, some safety mechanisms have been introduced through the KOSDAQ Rules. After an Initial Public Offering ("IPO") is made, the controlling shareholders of the company cannot sell the shares for six months following the IPO. See the KOSDAQ Rules, art 6.

19) But see Nobuyoshi Yamori and Taiji Baba, Japanese Management Views on Overseas Exchange Listings: 
As "the permission of cross listings will provide an opportunity to promote competition in the era of borderless global financial markets", the Korean government would "revise regulations governing disclosures and illegal stock trading to meet international standards and practices." ${ }^{20)}$ As mentioned above, implementation of this plan has reached completion in January 2002.

According to materials prepared by the Korean government, ${ }^{21)}$ cross-listing was necessary for the following reasons:

(i) diversification of funding options for small and medium-sized companies and start-ups in international capital markets;

(ii) promoting the growth of start-ups and small and medium-size companies with advanced technology by providing them with access to the overseas securities market;

(iii) promoting stability to the Korean securities market by reducing the imbalance between supply and demand;

(iv) enhancing the transparency and efficiency in management and corporate governance by means of globalization of the disclosure system, accounting system and practice in the securities industry; and

(v) strengthening the international competiveness of the domestic securities market.

Further, the government anticipates that, as the sophisticated foreign securities markets require a high level of transparency in terms of disclosure and management practices for the listing of companies, cross-listing will act as catalyst for improving the disclosure system and accounting system of the Korean companies. ${ }^{22)}$ In addition, according to the Korean government, the cross-listing will:

\footnotetext{
Survey Results, 12 Journal of International Financial Management and Accounting 286 (2001) (reporting that Japanese managers regard disclosure and financial reporting requirements as the primary obstacle to listing overseas).

20) See Korea Financial Supervisory Service Weekly Newsletter, January 12, 2000 , at 7.

21) See Korea Financial Supervisory Commission Press Release, March 30, 2002 (Korean) (on file with author).

22) Korea Financial Supervisory Commission Internal Memo re Cross-Listing of Public Companies on Foreign Exchanges, January 18, 2002 (Korean) (on file with author).
} 
(i) promote efforts to strengthen the competiveness of the Korean securities market by enhancing efficiency in trading and substantially reducing transaction costs by introducing international competitition to the Korean market;

(ii) enable the Korean market to cope with the global trends by establishing strategic alliances and/or co-operative relationships with the foreign securities markets; and

(iii) help the Korean exchanges install the infrastructure to globalize their operations through the adoption of international best practices.

\section{Regulatory Changes}

In order to prevent Korean companies from taking advantage of the cross-listing for unsound purposes, measures have been taken such as designation of qualified overseas stock markets for listing, the tightening of public disclosure requirements of Korean companies listing their shares on foreign securities markets, imposing reporting obligations on transfers of shares, etc. ${ }^{23)}$ Several foreign securities markets have been designated as qualified stock market for cross-listing such as NYSE, Nasdaq, American Stock Exchange, Tokyo Stock Exchange, London Stock Exchange, Deutsche Borse, Euronext Paris, Hong Kong Stock Exchange, Singapore Stock Exchange, among others. Korean companies wishing to list their shares on such foreign exchanges are required to make the necessary public disclosures (i) at the time they decide to cross-list, (ii) when the shares are actually listed on the foreign exchanges, and (iii) when such shares are delisted. In addition, Korean companies listed on the foreign exchanges are also obliged to make public announcement when they become subject to sanction for violating any of the public disclosure obligations under the applicable foreign laws and regulations. They are also required to disclose in the domestic market what they disclosed in foreign exchanges. ${ }^{24)}$

23) See Art. 69 Para.1 No. 18 and Para 6 of the Korea Financial Supervisory Commission Regulation on the Issuance of Securities and Disclosure.

24) $C f$. Section 6.5 of the German Corporate Governance Code: "Any information which the company discloses abroad in line with corresponding capital market law provisions shall also be disclosed domestically without delay." 


\section{The Market Reaction to Cross-Listings}

There are only three empirical studies available that focus particularly on the market reaction to cross-listing of Korean companies on foreign exchanges. ${ }^{25}$ )

One study on the impatcs of cross-listing of 21 Korean companies on domestic stock prices ${ }^{26)}$ demonstrated that cross-listing on certain foreign exchanges such as the NYSE, for example, raised stock prices in the domestic market prior to the crosslisting while decreasing the abnormal return and the level of systematic risk on the Korea Stock Price Index after the cross-listing. ${ }^{27)}$ On the other hand, this study found that cross-listing of Korean companies on other foreign exchanges such as the London Stock Exchange and Luxembourg Stock Exchange failed to bring about such impacts on the domestic market.

Another study ${ }^{28)}$ focusing on the issuance of overseas securities by 127 Korean companies between 1985 and 1995 shows that the issuance of such securities has had the effect of increasing the abnormal rate of return prior to public announcement of the issuance while decreasing the abnormal rate of return after the announcement. ${ }^{29)}$ This study, however, also suggested the possibility that the findings may have been affected by insider trading as the abnormal rate of return began rising one week prior to the public announcement of the issuance. Further, the extent of price fluctuation varied depending on such factors as the type of securities issued, the size of the issuer, etc. For instances, the extent of price movement was more obvious in case of BWs or DRs than in case of CBs, in case of preferred stock than in case of common stock, in case of large companies than in case of medium-sized companies.

There is also a report ${ }^{30}$ that analyses the price interactions for POSCO and KEPCO

25) For various studies on the effect of foreign listing on stock prices and expected returns, see Amir N. Licht, Regulatory Arbitrage for Real: International Securities Regulation in a World of Interacting Securities Markets, 38 Virginia Journal of International Law 563, 578-580 (1998).

26) Jae-Myung Kim and Hee-Joon Ahn, The Impacts of Cross-Listing on Domestic Stock Prices, 5-1 Jeungkwon Kumyung Yongu 1 (1999) (Korean).

27) Cf. Stephen R. Foerster and G. Andrew Karolyi, The Effects of Market Segmentation and Investor Recognition on Asset Prices: Evidence from Foreign Stocks Listing in the United States, 54 Journal of Finance 981 (1999).

28) Ho-Yun Jang, International Listing of Korean Stocks and Stock-related Securities and Its Impact on the Korean Stock Market, 8 Gukjegyungyoung Yongu 151 (1997) (available only in Korean).

29) Cf. Darius P. Miller, The Market Reaction to International Cross-Listings: Evidence from Depository Receipts, 51 Journal of Financial Economics 103 (1999). 
shares cross-listed on the NYSE. It concludes that the price in the Korea Stock Exchange influenced the open price in the NYSE, but not the other way around, i.e., no feed-back to home market was observed.

\section{Cross-Listing of Foreign Companies on Korean Exchanges}

As of this writing, no foreign firm has listed on any Korean exchange. In addition, no Korean Depository Receipts have been issued in Korea. The Korean government and exchanges wish to change the situation and solicit listings of foreign company shares, particularly from the East Asian countries. ${ }^{31)}$ Thus, understanding of economic and other positive impacts of cross-listing is important for not only for companies in Korea seeking to cross-list on foreign exchanges, but also for Korean exchanges seeking to solicit foreign issuers as well.

There are indications that foreign firms listing on Korean exchanges would have a sizable investor pool to tap into, as even non-institutional investors in Korea reportedly bought foreign securities in the aggregate of USD2.4 billion in 2001. While this is somewhat surprising given the high transaction costs involved and the degree of local regulatory restrictions, Korean securities companies, in co-operation with the KSD, have recently made the Home Trading System available for such investors, which will mean a substantial reduction in transaction costs. This again indicates that the Korean companies as well as the Korean exchanges need to cope with the global trends and accommodate the investors' needs. ${ }^{32)}$

As of July 2002, the Korean government created the necessary legal and

30) See Ho-Yun Jang, Cross-Listing of the Korean Shares on the NYSE and Price Interactions, 2-1 Jeungkwon Kumyung Yongu 105 (1996) (available only in Korean).

31) The Korea Stock Exchange acquired the status of a Designated Offshore Securities Market from the U.S. Securities and Exchange Commission in September 2000. See Korea Stock Exchange Press Release, Sept. 18, 2000.

32) Foreign companies are basically subject to the same quantitative and qualitiative listing standrads to be listed on a Korean exchange. However, there are some differences between the listing standards applicable to domestic firms and those applied to foreign firms. For example, a foreign company wishing to list on a Korean exchange is required to submit a legal opinion whereas Korean companies are not subject to such requirement. Furthermore, when submitting a business report, foreign companies must submit a copy of their public disclosure documents which have been submitted to the home country regulators, with the Korean translation. Differences between the accounting principles adopted by the foreign companies and Korean GAAP, the effect of such difference on the balance sheet of the foreign company and a summary of the financial statements of the foreign company for the latest 2 years to which Korean GAAP has 
institutional frameworks to promote the cross-listing of foreign companies on Korean exchanges. However, merely establishing such frameworks may not attract a reasonable number of foreign companies to cross-list on Korean exchanges. According to the bonding hypothesis, Korea should provide them with the market environment with much stronger regulations and enforcement so that foreign firms would see the opportunity to raise their value through the cross-listing. Therefore, we see here two sides of a coin. Korea should keep improving the corporate governance of the Korean firms ${ }^{33)}$ to get foreign firms cross-listed on Korean exchanges. This, again, can be best achieved through cross-listing of the Korean firms on foreign exchanges. ${ }^{34)}$

\section{Concluding Remarks}

The Korean case may be the only example that shows governmental adoption of the piggybacking paradigm ${ }^{35)}$ focusing on cross-listing. It remians to be seen if other developing countries follow the lead of Korea. It will ultimately depend on the outcome of the Korean efforts. The story of Korea is particularly interesting because it tells us the opposite of what many developing countries pursue in respect of migration of their firms to foreign markets. What caused Korea to adopt such a policy? Perhaps, it was the exogenous shocks it experienced durign the financial crisis in 1997 followed by the involvement of international lending agencies in an unprecedent sweeping reform process.

Many commentators suggest that national corporate governance systems reflect each nation's cultural values ${ }^{36)}$ and political and historical experiences. ${ }^{37)}$ It has also recently been suggested that each nation's legal system determines its corporate governance system. ${ }^{38)}$ Thus, nations will clearly exhibit differences in such systems,

been applied should also be submitted along with its audit report. See Arts. 39, 44, 48 and 49 of the Korea Financial Supervisory Commission Regulation on the Issuance of Securities and Disclosure.

33) See Table 4.

34) See generally Hwa-Jin Kim, Globalization of Corporate Finance and Restructuring of the Korean Securities Markets (Report to the Korea Stock Exchange, 2002) (Korean); Good Disclosure and Firm Value, 329 Korea Listed Companies Association Monthly Journal 6 (June, 2002) (Korean); Cross-Listing and Cross-Border Acquisitions of German Companies: Lessons for Korea, 43-2 Seoul Law Journal 28 (2002) (Korean); Recent Trends in Corporate Governance Studies, 1 KOSDAQ Listed Companies Association Quarterly Journal 54 (2001) (Korean).

35) See Bernard Black, The Core Institutions that Support Strong Securities Markets, 55 Business Lawyer 1565 (2000). 
often substantial. However, there are many reasons to promote universalism in corporate governance in light of globalization and integration of world's financial markets. ${ }^{39)}$ Cross-listing could facilitate competition among stock exchanges, ${ }^{40)}$ and as a consequence, regulatory competition and/or harmonization. ${ }^{41)}$ Such developments will inevitably pose a yet different and new kind of jurisdictional conflict, but, at the same time, will also promote the discussion and study of international norms, either bilateral or multilateral, that address international securities laws, ${ }^{42)}$ and ultimately contribute to the development of universal standards for the corporate disclosure and accounting systems with a world-wide applicability. The outcome of such discussions and studies will assist the policy makers and regulators of the emerging market countries, including Korea, in developing strategic plans for reforms to their corporate and securities laws, as well as the international organizations in carrying out their private sector development programs.

36) See, e.g., Amir N. Licht, The Mother of All Path Dependencies: Toward a Cross-Cultural Theory of Corporate Governance Systems, 26 Delaware Journal of Corporate Law 147 (2001).

37) See, e.g., Lucian A. Bebchuk \& Mark J. Roe, A Theory of Path Dependence in Corporate Governance and Ownership, 52 Stanford Law Review 127 (1999); Mark J. Roe, Strong Managers, Weak Owners: The Political Roots of American Corporate Finance (1994); John C. Coffee, Jr., The Rise of Dispersed Ownership: The Role of Law in the Separation of Ownership and Control, 111 Yale Law Journal 1 (2001).

38) See Rafael La Porta et al., Investor Protection and Corporate Governance, 58 Journal of Financial Economics 3 (2000); Rafael La Porta et al., Legal Determinant of External Finance, 52 Journal of Finance 1131 (1997).

39) See Black, supra note 1, at 544 (" $[\mathrm{M}]$ any of the core problems of corporate governance are universal, and... the range of reasonable solutions is finite.") Cf. Henry Hansmann \& Reinier Kraakman, The End of History for Corporate Law, 89 Georgetown Law Journal 439 (2001).

40) See John C. Coffee, Jr., The Coming Competition Among Securities Markets: What Strategies Will Dominate? (Working Paper, September 2001), available at <http://papers.ssrn.com/paper.taf?abstract_id=283822> (SSRN); Amir N. Licht, Stock Exchange Mobility, Unilateral Recognition, and the Privatization of Securities Regulation, 41 Virginia Journal of International Law 583 (2001). See also Nasdaq and Its Rivals: Uncertain Future, The Economist, May 25, 2002, at 67, 68 (quoting Larry Harris: "Competition among exchanges is fiercer than among airlines.”)

41) See Howell E. Jackson, Centralization, Competition, and Privatization in Financial Regulation, 2 Theoretical Inquiries in Law 649 (2001); Marc I. Steinberg \& Lee E. Michaels, Disclosure in Global Securities Offerings: Analysis of Jurisdictional Approaches, Commonality and Reciprocity, 20 Michigan Journal of International Law 207 (1999); Uri Geiger, Harmonization of Securities Disclosure Rules in the Global Market - A Proposal, 66 Fordham Law Review 1785 (1998).

42) Korea is going to host the 28th Annual Conference of the International Organization of Securities Commissions in 2003. See <http://www.iosco.org>; Korea Financial Supervisory Commission Press Release, May 19, 2000 (emphasizing the role of Korea in the development of international capital markets). 


\section{[ Table 1] Korean Companies Listed on NYSE and Nasdaq}

\begin{tabular}{lllc}
\hline & Company & Listed & ADR \\
\hline NYSE $^{1)}$ & Kookmin Bank & Nov. 1, 2001 & $*$ \\
& Korea Electric Power Corporation & Oct. 27, 1994 & $*$ \\
& KT Corporation & May 26, 1999 & $*$ \\
& POSCO & Oct. 14, 1994 & $*$ \\
& SK Telecom Co., Ltd. & June 27, 1996 & $*$ \\
& Korea Thrunet Co., Ltd. & Nov. 17, 1999 & $*$ \\
Nasdaq $^{2)}$ & Hanaro Telecom, Inc. & March 29, 2000 & $*$ \\
& Mirae Corporation & Nov. 17, 1999 & \\
\hline
\end{tabular}

1) As of September 17, 2002

2) As of October 14, 2002

[ Table 2 ] Number of Asian and Israeli Companies Listed on NYSE and Nasdaq

\begin{tabular}{lcc}
\hline & NYSE $^{1)}$ & Nasdaq $^{2)}$ \\
\hline Korea & 5 & $3(1)$ \\
China & 13 & - \\
Hong Kong & $9(4)$ & $11(8)$ \\
India & 8 & 3 \\
Indonesia & 2 & - \\
Japan & 18 & 16 \\
Philippines & 1 & 1 \\
Taiwan & 4 & 2 \\
Singapore & $1(1)$ & $7(5)$ \\
Israel & $5(2)$ & $74(68)$ \\
\hline
\end{tabular}

1) As of September 17, 2002 (468 Companies from 51 Countries)

2) As of October 14, 2002 (389 Companies from 39 Countries) 


\section{[ Table 3 ] Shareholdings of Major Shareholders in 10 Largest*}

Chaebols in Korea (*as of the end of 2000)

\begin{tabular}{lcccc}
\hline & Family & Affiliate Firms & Treasury Shares, etc. & Total \\
\hline Jan. 1, 1998 & 6.86 & 18.44 & 1.21 & 26.51 \\
Jan. 1, 1999 & 5.94 & 28.17 & 2.50 & 36.60 \\
Jan. 1, 2000 & 4.34 & 22.96 & 2.87 & 30.17 \\
Dec. 31, 2000 & 4.60 & 22.52 & 4.72 & 31.84 \\
\hline
\end{tabular}

Source: Korea Stock Exchange Press Release, Jan. 29, 2001

\section{[ Table 4] Survey of Corporate Governance Practices in 465 KSE-listed Companies}

\begin{tabular}{ll}
\hline Cumulative Voting (Default Rule) & 158 companies (22.4\%) \\
Vote by Mail (Opt - in) & 106 companies (15.1\%) \\
Average Number of Directors & 6.5 \\
Board Meetings per month & 1.8 \\
Foreign Directors & 53 companies (2.3 per company) \\
Audio - visual Board Meeting (Default Rule) & 188 companies (in practice) \\
Derivative Litigation (past 3 years) & 10 companies \\
Minority Shareholders' & $35.7 \%$ \\
Shareholders Meeting Attendance Rate & 91 companies $(12.9 \%)$ \\
Audit Committee & 117 companies $(25 \%)$ \\
D\&O Insurance for Outside Directors & \\
\hline
\end{tabular}

Source: Korea Stock Exchange Press Release, Nov. 29, 2000 


\section{[ Table 5 ] Foreign Ownership in Major Korean Companies}

\begin{tabular}{lll}
\hline & $1998-12$ & $2002-7$ \\
\hline Samsung Electronics & 49.34 & 53.20 \\
SK Telecom & 33.56 & 30.70 \\
KT & 0.03 & 37.20 \\
Korea Electric Power & 19.93 & 24.70 \\
POSCO & 38.10 & 58.90 \\
Hyundai Motor & 15.08 & 50.60 \\
\hline
\end{tabular}

Source: Korea Stock Exchange

[ Table 6 ] The Korea's Largest Corporations (2001)

\begin{tabular}{rlrc}
\hline Rank & \multicolumn{1}{c}{ Company } & $\begin{array}{c}\text { Market Cap. (KRW millions) } \\
\text { (Dec. 28, 2001) }\end{array}$ & $\begin{array}{c}\text { Financial Times } \\
\text { Global Rank }\end{array}$ \\
\hline 1 & Samsung Electronics & $42,220,609$ & 85 \\
2 & SK Telecom & $23,892,915$ & 221 \\
3 & KT & $15,594,372$ & 328 \\
4 & Kookmin Bank & $14,924,933$ & 338 \\
5 & Korea Electric Power & $13,890,189$ & 383 \\
6 & Pohang Iron \& Steel & $11,417,917$ & 453 \\
7 & Korea Telecom Freetel & $7,798,446$ & - \\
8 & Hyundai Motor & $5,893,486$ & - \\
9 & Shinhan Financial Group & $5,130,640$ & - \\
10 & LG Electronics & $3,846,928$ & - \\
11 & Korea Tobacco \& Ginseng & $3,705,242$ & - \\
12 & Kookmin Credit Card & $3,660,000$ & - \\
13 & Kia Motors & $3,274,633$ & - \\
14 & Samsung Electro-mechanics & $3,271,583$ & - \\
15 & Cho Hung Bank & $2,811,383$ & - \\
\hline
\end{tabular}

* Source: The Hankyung Business Weekly (May 20, 2002)

Financial Times 